\title{
Intratracheal Dental Prostheses as a Rare Cause of Chronic Stridor and Dyspnea
}

\section{Osvaldo Araujo Ramirez*}

Instituto Mexicano del Seguro Social, Centro Médico Nacional de Occidente, Mexico

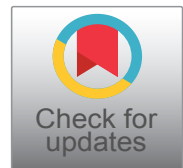

*Corresponding author: Osvaldo Araujo Ramirez, MD, Instituto Mexicano del Seguro Social, Centro Médico Nacional de Occidente, Central \#1 Villa California, Tlajomulco de Zuñiga Jalisco, C.P. 45645, Mexico, Tel: 3310414274

\begin{abstract}
The human larynx is a complex organ, playing a major role in the protection of the lower airway; It's unusual for a foreign body to be inhaled rather than swallowed and when it happens constitutes a real life-threatening emergency. We present a case of a middle age female with a 13-month history of stridor and dyspnea, managed and treated as an asthma patient. After the airway was secured a direct microlaryngoscopy was performed removing the obstruction resulting to be a dental prostheses $50 \mathrm{~mm}$ long. This kind of pathology has to be suspected and correctly diagnosed and treated to prevent further complications.
\end{abstract}

\section{Introduction}

The human larynx is a complex organ that functions as a sphincter in the aerodigestive and respiratory tract junction and plays a major role protecting the airway $[1,2]$. For this reason, it is unusual for a foreign body to be inhaled rather than swallowed [2,3]. However, when occurs, constitutes a real emergency, requiring immediate medical attention when airflow obstruction is involved [4]. Foreign body aspiration in adults is rare and usually shows nonspecific symptoms and most of them go unnoticed especially if the situation is chronic [5].

\section{Case Report}

We present the case of a 49-year-old female with 13-month history of biphasic stridor and dyspnea, with history of epilepsy treated with levetiracetam and no other important comorbidities. The patient was sent to our service with the diagnosis of subglottic stenosis since her symptoms began thirteen months ago and was treated for misdiagnosed asthma and chronic bronchitis, Nebulized steroid and bronchodilators were pre-

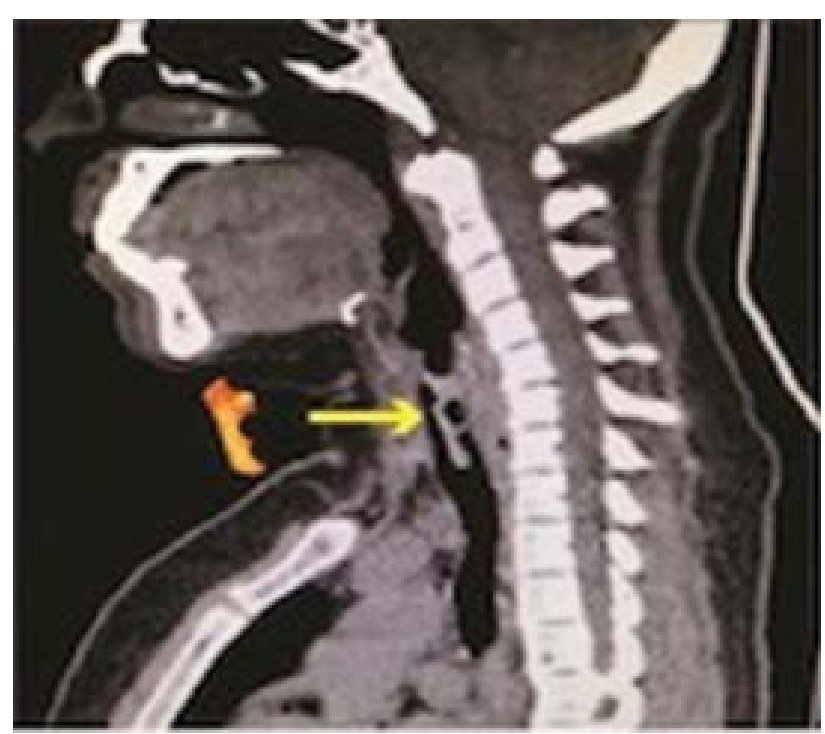

Figure 1: Sagittal CT scan with the soft tissue isodense obstruction in the airway (arrow).

scribed having partial remission of symptoms, slowly progressing with the expiratory dyspnea and stridor.

The rigid laryngoscopy showed a subglottic mass occluding $70 \%$ of the light, with preserved chordal mobility.

Computer Tomography (CT) performed as a diagnosis protocol showed in the tracheal lumen a soft tissue isodense mass extending from subglottis to the $3^{\text {rd }}$ tracheal ring, approximately $5 \times 10 \times 5 \mathrm{~mm}$ wide, with irregular edges (Figure 1, Figure 2 and Figure 3 ).

A tracheotomy was performed under local anesthesia followed by a direct microlaryngoscopy, achieving

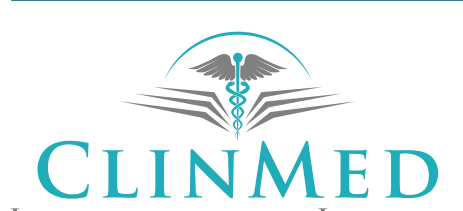

INTERNATIONAL LIBRARY
Citation: Ramirez OA (2018) Intratracheal Dental Prostheses as a Rare Cause of Chronic Stridor and Dyspnea. Int J Oral Dent Health 4:064. doi.org/10.23937/2469-5734/1510064

Accepted: October 18, 2018: Published: October 20, 2018

Copyright: (C) 2018 Ramirez OA. This is an open-access article distributed under the terms of the Creative Commons Attribution License, which permits unrestricted use, distribution, and reproduction in any medium, provided the original author and source are credited. 


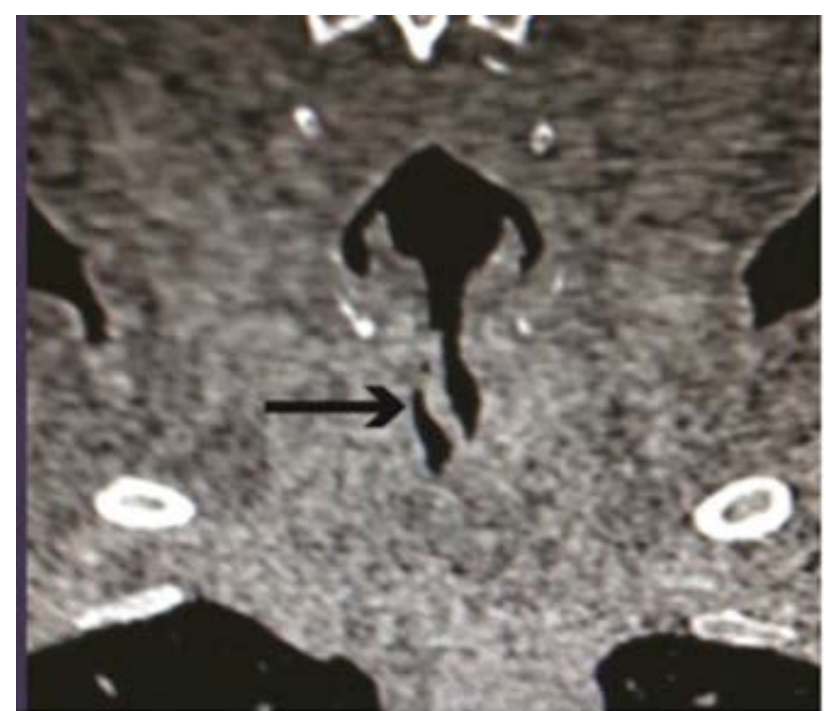

Figure 2: Coronal CT scan with the obstruction resembling a membrane or granulation tissue (arrow).

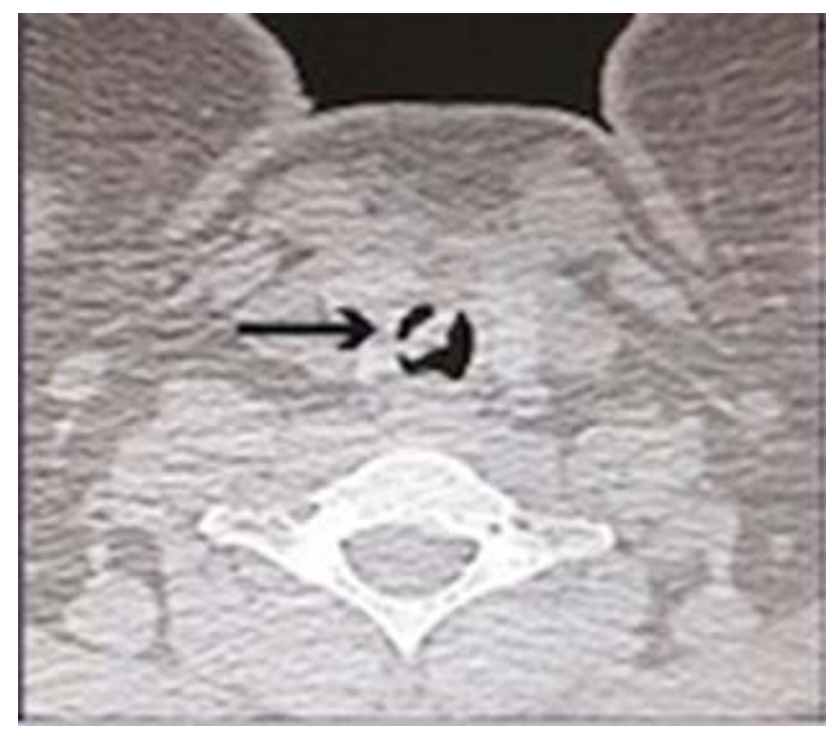

Figure 3: Axial CT scan showing the level of obstruction (arrow).

the removal of the intratracheal mass. The extracted object resulted to be a dental prosthesis about $50 \mathrm{~mm}$ long that was surrounded by granulation tissue, which was removed with laryngeal microelectrodes (Figure 4 and Figure 5).

The patient was decanulated a week later with no other complication.

\section{Discussion}

The foreign body aspiration is way more common in children than in adults [6,7], approximately $80 \%$ of the reported cases are children younger than 15 -years-old $[8,9]$. A history of aspiration can be documented when the patient presents acute symptoms [10], however, when the story is chronic only $3.4 \%$ of patients remember the event. The symptoms may differ according to the location with partial obstruction stridor, hoarseness, cough, sore throat, wheezing and dyspnea. This symp-

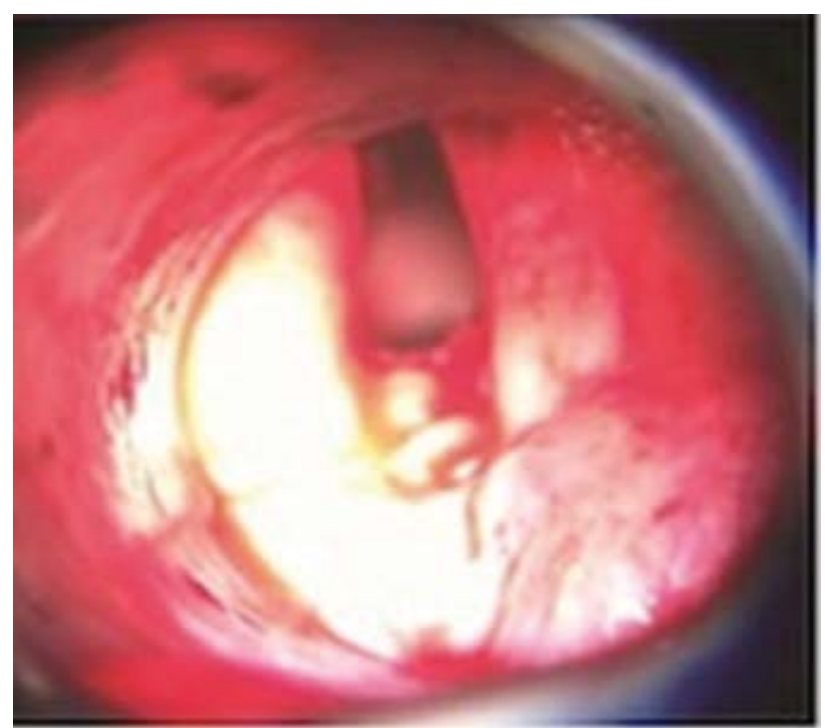

Figure 4: Transoperatory photograph after removing the strange body, with the granulation tissue underneath it.

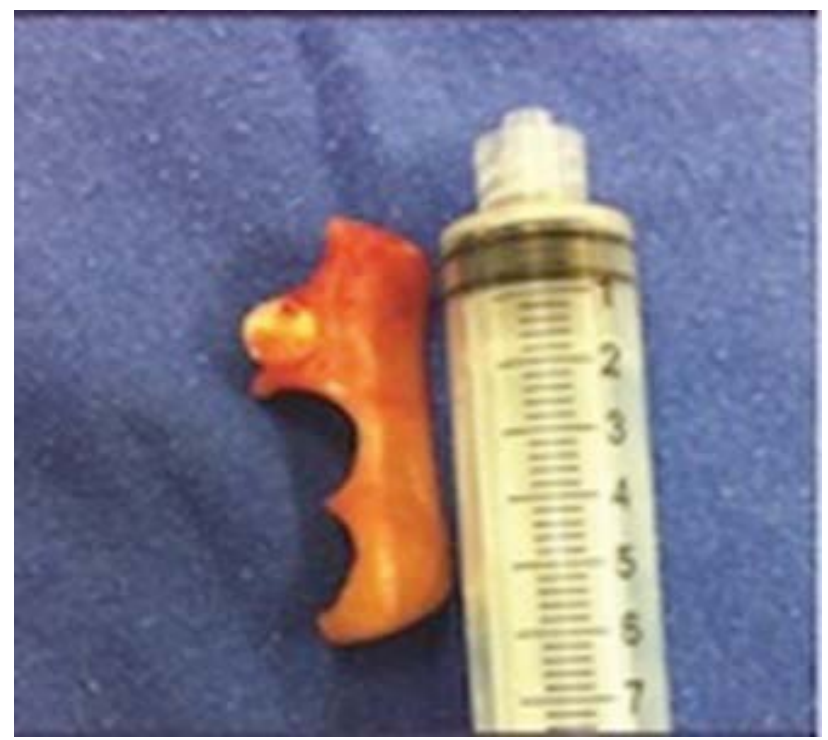

Figure 5: Dental prostheses after removal.

tomatology often suggests diagnoses of other pathologic processes especially when the history of aspiration is not remembered.

The nature of a foreign body varies significantly according to the cultural and geographic differences in the world [11-13]. Foreign body aspiration although is a rare complication of seizures it derives from a combination of factors, such as impaired swallowing mechanisms and difficulty in attaining adequate patient positioning [14]. The most common aspirated foreign body is food related $[8,15]$, while dental prostheses as in this case, represents up to $27 \%$ of cases in adults.

Foreign bodies may go unnoticed for months causing unresolved pneumonia, bronchiectasis $[6,16]$ and lung abscesses, leading to the formation of granulation tissue around the foreign body resembling a tracheal tumor [17]. 


\section{Conclusions}

A foreign body aspiration is a well-recognized complication of orthodontic practice that's why the emphasis on performing and appropriate technique of affixing the dental prostheses to prevent aspirations and to manufacture them with radiopaque materials to prevent misdiagnose. Therapeutic removal of a foreign body can be done through a fiberoptic bronchoscopy with a success rate of extraction in adults of $60-90 \%$. The removal through direct microlaryngoscopy is the most recommended technique, since the surrounding granulation tissue can be resected during the surgical procedure, preventing the organization of subglottic fibrosis.

\section{Financial Disclosure}

The Authors have no relevant financial or nonfinancial relationships to disclose.

\section{Conflict of Interest}

The Authors have no conflicts of interest to disclose.

\section{References}

1. Amari FF, Fans KT, Mahafza TM (2000) Inhalation of wild barley into the airway: Two different outcomes. Saudi Med J 21: 468-470.

2. Cataneo AJ, Reibscheid SM, Ruiz Júnior RL, Ferrari GF (1997) Foreign body in the tracheobronchial tree. Clin Pediatr 36: 701-705.

3. kent SE, Watson MG (1990) Laryngeal foreign bodies. J Laryngol Otol 104: 131-133.

4. Umapathy N, Panesar J, Whitehead BF, Taylor JFN (1999) Removal of a foreign body from the bronchial tree-A new method. J Laryngol Otol 113: 851-853.

5. Ferreres-Franco, Blanquer-Olivas (2005) Sindromeasfictico por molde. Bronqual Arch Bronconeumol 41: 638-640.
6. Mehta RM, Pathak PN (1973) A foreign body in the larynx. $\mathrm{Br} \mathrm{J}$ Anesth 45: 7856.

7. Jackson LC (1936) Endoscopy of foreign body. Review of 178 cases of foreign body in the air and food passages. Ann Otol 45: 644

8. Luis Carlos Hinojos Gallardo, Mauricio Silva Barragán, Moisés Dante Escobedo Sánchez, Alejandro Alejandre García (2011) Diagnostico tardio de aspiracion de cuerpo extraño. Bol Med Hosp Infant Mex 68: 220-224.

9. Boyd M, Chatterjee A, Chiles C, Chin R Jr (2009) Tracheobronchial foreign body aspiration in adults. South Med J 102: 171-174.

10. Baharloo F, Veyckemans F, Francis C, Biettlot MP, Rodenstein DO (1999) Tracheobronchial foreign bodies: Presentation and management in children and adults. Chest 115: 1357-1362.

11. Tariq $P$ (1999) Foreign body aspiration in children: A persistent problem. JPMA 49: 33-36.

12. Foltran F, Passali FM, Berchialla P, Gregori D, Pitkäranta $A$, et al. (2012) Toys in the upper aerodigestive tract: New evidence on their risk as emerging from the susy safe study. Int J Pediatr Otorhinolaryngol 76: 61-66.

13. Brkic F, Umihanic S (2007) Tracheobronchial foreign bodies in children. Experience at ORL clinic Tuzla, 1954-2004. Int J Pediatr Otorhinolaryngol 71: 909-915.

14. DeToledo JC, Lowe MR, Gonzalez J, Haddad H (2004) Risk of aspiration pneumonia after an epileptic seizure: A retrospective analysis of 1634 adult patients. Epilepsy Behav 5: 593-595.

15. Roda J, Nobre S, Pires J, Estêvão MH, Félix M (2008) Foreign bodies in the airway: A quarter of a century's experience. Rev Port Pneumol 14: 787-802.

16. McGuirt WF, Holmes KD, Feehs R, Browne JD (1988) Tracheobronchial foreign bodies. Laryngoscope 98: 615-618.

17. Weissberg D, Schwartz I (1987) Foreign bodies in the tracheobronchial tree. Chest 91: 730-733. 